Journal of Sustainability Perspectives

journal homepage: https://ejournal2.undip.ac.id/index.php/isp/

\title{
Sustainable Development at University of Pécs
}

\author{
Orbán, $K^{1,}{ }^{1}$, Kulcsár, $T^{2}{ }^{2}$, Radvánszky, $B .^{3}$ \\ ${ }^{1,2}$ Chancellery, Technical Service Directorate, Technical Department, 7633 Pécs Szántó K. J. u. 1/b., University \\ of Pécs, Hungary \\ ${ }^{3}$ Chancellery, Technical Service Directorate, X-ray Protection Service, 7633 Pécs Szántó K. J. u. 1/b., University \\ of Pécs, Hungary \\ *corresponding author: orban.krisztina@pte.hu
}

Article Info

Received:

15 March 2021

Accepted:

25 May 2021

Published:

1 August 2021

DOI:

Presented in The $6^{\text {th }}$ International (Virtual) Workshop on UI GreenMetric World University Rankings (IWGM 2020)
Abstract Since 2016, the University of Pécs (UP) has participated in the UI GreenMetric World University Ranking. Thanks to its conscious, disciplined environmental ambitions and related achievements, UP has been able to move forward year after year in the ever-expanding rankings and in 2019 it has been ranked among the top 100 greenest universities in the world. UP believes that sustainability must be achieved not only in its operations and university-related services but also in the internal and external natural, social and economic environment associated with the university. UP presents its sustainable development efforts along the lines of achievements in the natural, social and economic environment and explores its future visions. UP stated its mission, that every useful practice, innovation, management in the environment tend to help sustainability and sustainable administration has to be encouraged, with the aid of education and science aiming to strengthen ecological consciousness. It was realized in the spirit of this mission, the development of the 24,8 billion HUF Modern Cities Programme for the built infrastructure of UP, the award of the title "Responsible Employer of the Year" in 2019, the award of the "Energy Efficient Institution" award as the first Hungarian university and the award of the Baranya County Environmental Prize was achieved. In the social and economic environment, as an Energy Efficiency Mentor organization, UP established the Baranya Virtual Power Plant Program in 2019, which, together with social and economic actors, saved 3.5 MW of energy in the South Transdanubian region of Hungary within 1 year. With the support of the Visegrad Fund, UP is trying to build a network of universities between the Visegrad countries and the universities of the Danube Region, where the fight against climate change will become even more effective by means of shaping attitudes. The University of Pécs intends to increase its environmental ambitions in the future.

\section{Keyword:}

Energy consciousness, energy efficiency, responsibility, sustainability, University of Pécs (Hungary). 


\section{Introduction}

The University of Pécs (UP) is the first university in Hungary, higher education in this country dates back 650 years. Today's UP was created as a result of a multi-stage integration process. UP has locations in several cities in the South Transdanubia (Fig. 1).

UP is one of the largest universities in Hungary due to the number of its university citizens (students, faculty, researchers and other workers), the area and the budget of the university (Table 1). UP consists faculties spanning 10 disciplines and a Clinical Center. The Clinical Center provides to 900,000 people with 29 clinical units across the South Transdanubian region.

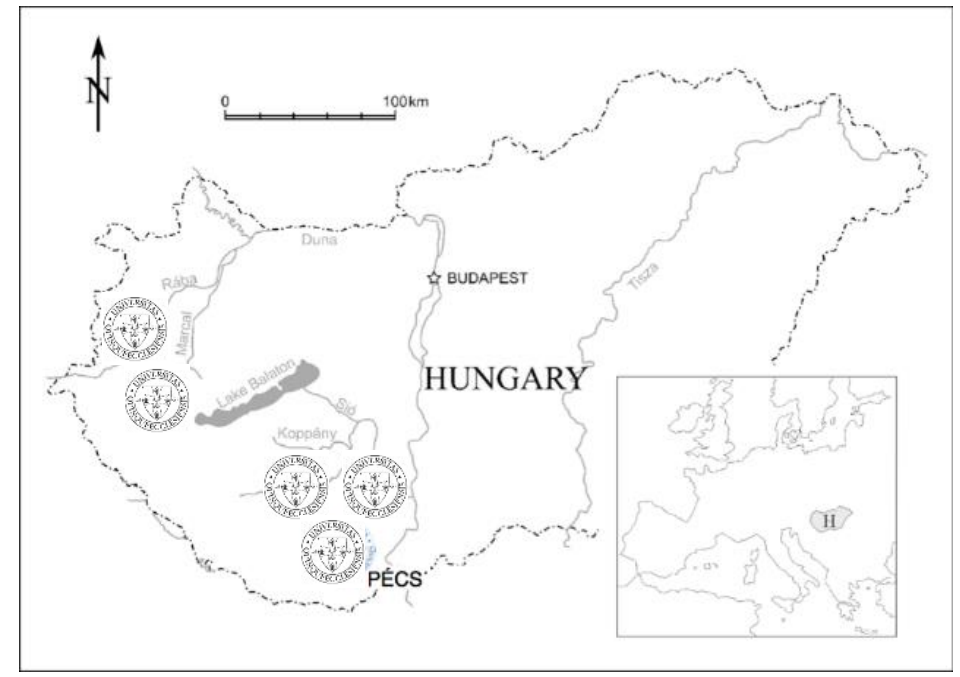

Figure 1. Campus locations of the University of Pécs, Hungary

Table 1. Setting and infrastructure of the University of Pécs

\begin{tabular}{c|c|c|c|c|}
\hline 2016 & 1.579 .781 & 471.193 & 19.799 & 6.434 \\
\hline 2017 & 1.588 .397 & 472.956 & 19.937 & $\mathbf{6 . 9 5 3}$ \\
\hline 2018 & $\mathbf{1 . 3 2 6 . 5 6 1}$ & $\mathbf{4 7 3 . 1 2 9}$ & $\mathbf{1 8 . 1 0 7}$ & $\mathbf{7 . 1 7 0}$ \\
\hline 2019 & $\mathbf{1 . 3 4 2 . 7 6 0}$ & $\mathbf{5 7 9 . 1 6 5}$ & $\mathbf{2 0 . 8 9 0}$ & $\mathbf{7 . 3 8 7}$ \\
\hline & $\begin{array}{c}\text { Total campus } \\
\text { area (m²) }\end{array}$ & $\begin{array}{c}\text { Total campus } \\
\text { buildings } \\
\text { area (m²) }\end{array}$ & $\begin{array}{c}\text { Total number } \\
\text { of regular } \\
\text { students }\end{array}$ & $\begin{array}{c}\text { Total number } \\
\text { of academic } \\
\text { and }\end{array}$ \\
\hline & & $\begin{array}{c}\text { administrative } \\
\text { staff }\end{array}$
\end{tabular}

Education and health services associated with UP's activities have a significant impact on the environment. In order to reduce impacts and adapt to environmental changes, UP has set the objective of ensuring sustainability of education and health services. The UI GreenMetric World University Ranking is a marginal condition for university endeavors. UP joined the UI GreenMetric World University Ranking in 2016, promoting the Green University Program. Thanks to the university's increasingly conscious environmental efforts and achievements, UP was ranked 100th in 2019 in the UI Green Metric World University Ranking (Fig. 2) [1]. 


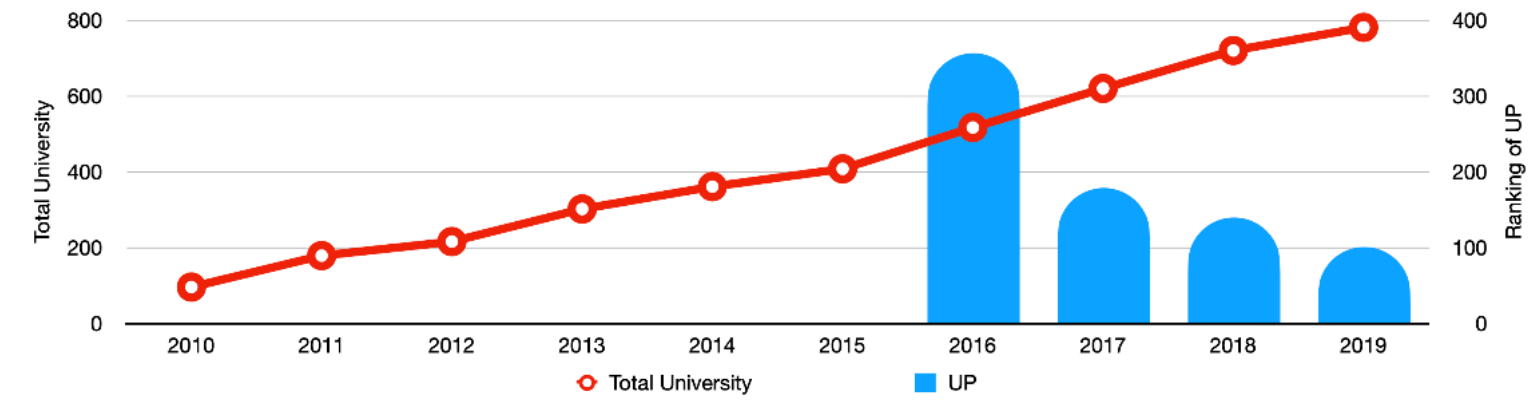

Figure 2. Positions of University of Pécs in the UI GreenMetric World University Ranking

The achievements in the UI GreenMetric World University Ranking and the current university infrastructure developments provide UP with the opportunity to achieve sustainability not only in its operations and university-related services, but also in the internal and external natural, social and economic environment connected to the university. In this article, UP describes the sustainable development efforts in the natural, social and economic environment, the results achieved, and future visions.

\section{Results}

\subsection{Results of environmetal responsibility}

Under the "Modern Cities Programme (2015-2020)" announced and supported by the Government of Hungary, the development of UP's current infrastructure and the expansion of its modern equipment asset will be implemented. The improvements that have already been made and are still under way will enable the university to strengthen its competitiveness, to develop its education and services portfolio, to increase the number of students abroad and to ensure the necessary infrastructure conditions. Currently 14 different development projects of the UP are carried out at variable departments.

The expanding university infrastructure further enhances the close interaction of environmental spheres within the city of Pécs in a heavily transformed meta hemerobic [2] environment. In order to reduce the environmental impact, the university intends to reduce its carbon footprint (Fig. 3), keeping an eye on natural and academic interests. The University has consciously articulated its mitigation efforts recently, which are in line with the decarbonization goals of the national "Second National Climate Change Strategy" [3].

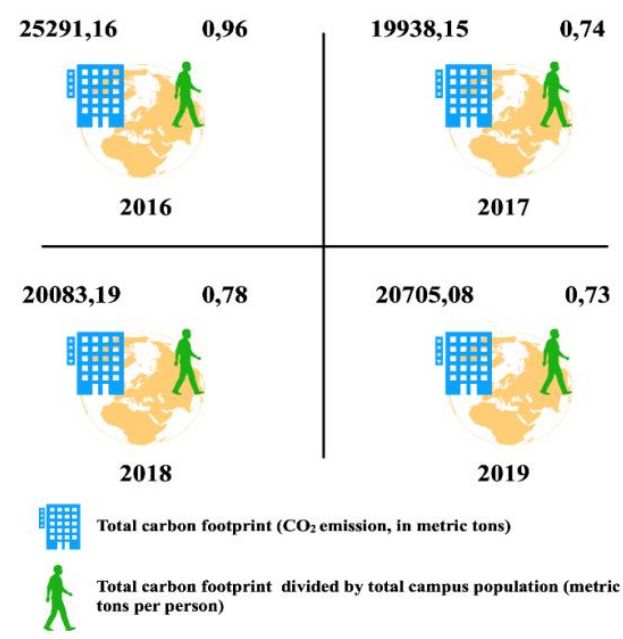

Figure 3. Carbon footprint of the University of Pécs 
The first cornerstone of the university's decarbonization roadmap is the replacement of fossil fuels with renewable energy sources. The share of renewable energy sources used out of the total usage by UP has been steadily increasing since $2016.53 \%$ of the total energy consumed by the University in $2019(36956,561 \mathrm{kWh})$ from renewable energy sources. Biomass has the largest share of renewable energy sources (97\%), due to the switchover to district heating based on biomass. Biomass is followed by geothermal and solar energy (Fig. 4). The university's fleet of cars has also managed to reduce the share of fossil fuels by three times the price of electric cars.
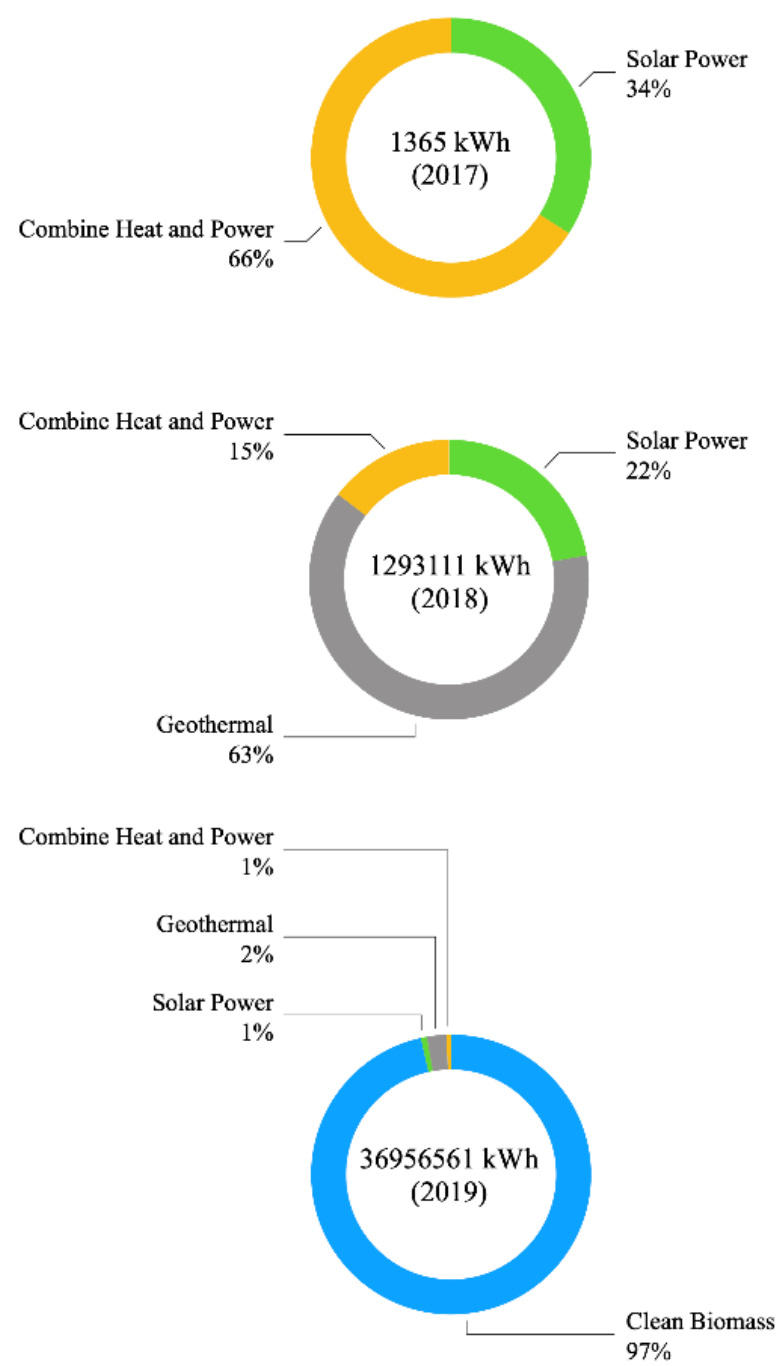

Figure 4. Renewable energy sources at the University of Pécs

The second point of the university's decarbonization roadmap is to increase energy efficiency and energy savings. UP's achievements in the field of energy efficiency have given the University the opportunity to join the Virtual Power Plant Program (VPPP) [4] which the European Union has declared one of the top energy efficiency programs for sustainable development. The essence of VPPP is to achieve the real energy savings through transformation of mind-set.

Within the framework of the program, UP was the first of the Hungarian universities to receive the "Energy Efficient Institution" award in 2019, and the university's practice schools received the "Energy Conscious School" appreciation. 
UP supports the promotion of technologies, services and consumer habits that seek to reduce the use of natural resources, achieving decarbonization goals. UP stands by its citizens to participate university innovation house building competition called Solar Decatlon. Model house in 2019, registered in a consortium of the University of Pécs, the University of Miskolc and the Algiers Blidai Saad Dahlad University ranked 2nd in category of architecture and ranked 3rd in the category of energy efficency at Hungarian Nest+ project. The cube house reinterpreted by university students is a low budget, passive renovation defined by implementation of energy efficient vernacular elements, and a design a complementer with the one above technological excellence demanding extra energy newly built house [5]. The university is also making mitigation efforts in the area of waste management, reducing the amount of waste generated at the university and reducing it. From 2019, UP has ceased the purchase and distribution of pet-bottle beverages in its territory. In order to implement the local decision, 70 water filling stations have been placed for university citizens. A key objective is to further reduce the amount of general waste, which is used for selective waste collection at all sites. The selective waste collection forms have a unified face, which is an integral part of institutional waste management policy.

UP increases the capacity of natural sinks in the university environment to enhance its decarbonization results. In addition to increasing the sinks, the university, planted 650 saplings in the recultive area nearby, creating a park for recreational purposes. In the current infrastructure development, "greening" is an important consideration as far as possible, so that in the construction of a new theoretical block of the Faculty of Medicine, the $10,000 \mathrm{~m}^{2}$ interior park, increasing the amount of carbon dioxide absorption in urban space.

Environmental efforts are carried out at the university under the Green University Program. The Green University Program is led by the Technical Services Directorate of Chancellery. The staff of the university's departments will help implement the programme on a voluntary basis and on their work.

\subsection{Results of social resposibility}

UP considers social responsibility to be important in order to ensure sustainable operation with a view to the social acceptance of environmental achievements achieved so far and the increase in oikophilia [6]. The social responsibility of the UP extends to the citizens of the university and to the urban population outside the university. The university received the "Responsible Employer of the Year 2019" award for respecting its employees and creating appropriate working conditions. In addition to the "Responsible Employer of the Year 2019", the university was awarded the title "Family Friendly Workplace 2019" and the bronze degree from the Family Friendly Place Certification Mark. The evaluations examined the university's practices in 11 topics, including employment, benefits and services, family-friendly attitudes, community building efforts, health promotions, corporate policy and policies. The University professes that by the full appreciation of employees the institutional discipline increases as the efficiency in shaping attitudes under the Green University Program also, which has an energy awareness and energy efficiency dimension at institutional level [7]. The program implemented among employees are organized by the UP Chancellery Human Policy Directorate.

UP takes full responsibility for students through all educational and other practical methods. Within the framework of the Green University Program, the university has initiated nearly 100 environmental related approach forming actions in various sectors of 
the environment, such as energy use, transport, waste management and water management. The actions are partly related to university initiatives and national and global actions. The largest and most significant university approach programs and their results are set out on the Green University Program website [8].

For UP, it is important to socially sensitize students and to build and support their environmentally conscious lifestyles, with an emphasis on self-organizing bottom-up initiatives. The university rewards active students with an extra point in their admission to college and gives them the opportunity to participate in university events.

In addition to its institutional social responsibility, UP initiated the cooperation of the Hungarian universities participating in the UI GreenMetric World University Ranking. UP believes that universities can act effectively together to promote environment consciousness and sustainable development. For this reason, UP has organized the Green workshop for representatives of the nine Hungarian universities for the second time in 2019. UP and the University of Szeged, as the national coordinator of the UI GreenMetric World University Ranking, intends to turn on the network of universities participating in international rankings for the purpose of good practices and knowledge sharing. UP, with the support of the Visegrad Fund, develops international cooperation between the universities of the three Visegrad and two other neighbouring states participating in the UI GreenMetric World University Ranking. The aim of the cooperation of universities in the common ranking is to share knowledge and implement joint efforts in Central Europe through the UI GreenMetric World University Ranking network to combat climate change [9].

\subsection{Results of economic responsibility}

UP supports all initiatives to promote sustainability and environmental awareness in the social and economic space, in accordance with its mission. UP, Hungarian Innovation and Efficiency Nonprofit Ltd., the Municipality of Pécs County, the Diocese of Pécs, the Baranya County Council, the Chamber of Commerce and Industry of Pécs-Baranya, the Leőwey Klára secondary school and the director and patron of VPPP signed a letter of intent in 2019 with a view to achieving energy awareness, energy efficiency and green energy developments in South Transdanubia. The parties of the letter of intent have agreed to establish and operate the Baranya Virtual Power Plant Programme (BAVPPP) [10]. BAVPPP participants have set out number of specific action packages across different sectors to reduce greenhouse gas emissions. Joint cooperation has resulted in a program called 'Zero Emission Days'. In addition to the objective of mitigating the event, an important indirect objective was to increase the urbanisation of Pécs. The population participating in the action saved $296 \mathrm{~kg}$ of $\mathrm{CO}_{2}$ equivalent greenhouse gases by using zero or near null means of transport for a week to get to work [11]. BAVPPP 's economic operators also implement bilateral cooperation to increase energy efficiency and energy awareness. During BAVPPP 's one-year operation, the program's participants saved 3.5 MW of energy across the South Transdabubian region.

\section{Summary}

The environmental results achieved by UP are significant. The results provide UP with a motivation to develop and implement additional operational action plans. The results so far relate to UP's entire operating area and the wider environment of it. Complex sustainability efforts provide an opportunity to address the challenges in a holistic way. In 
the UI GreenMetric World University Ranking, the sub-results of the UP-ranking show sectors such as the energy and climate, waste management and transport, where further fine tuning and knowledge sharing can be used to achieve new results in order to deepen environmental awareness. Progress is needed in mind-set and water management. The relative lag in attitude formation comes from the fact that the results achieved under the Green University Program are mainly technical. The social acceptance of these results should be increased in the future, which is why the Chancellery of UP has initiated a conscious commitment to social and economic responsibility.

Further results in water management are already beyond UP's level, so projects that can be implemented jointly with economic, municipal and government actors can help achieve sustainable results in the field of mitigation or adaptation to environmental impacts. For example, sustainable municipal water management can be achieved in Pécs in partnership with UP.

In the future, UP intends to increase its environmental ambitions and will make every effort to promote environmental awareness-raising, energy-saving and sustainable solutions vertically and horizontally in the long-ago natural, social and economic environment of South Transdanubian region.

\section{References}

1. UI GreenMetric, 2020. UI GreenMetric World University Ranking. Available online at http://greenmetric.ui.ac.id/, accessed on 11, 05, 2020

2. Szilassi, P., Bata, T., Molnár, Zs., 2016. A táj antropogén átalakítottságának térképezése országos léptékben Magyarország példáján (Mapping the landscape of anthropogenic transformation on a national scale by Hungary). In: Tájökológiai Konferencia. Szeged. Available online

at https://tajokologiaikonferencia.hu/media/downloads/Szilassi_et_al.doc

3. Második Nemzeti Éghajlatváltozási Stratégiai (The Second Climate Change Strategy of Hungary), 2018. In: 23/2018. (X. 31.) OGY határozata 2018-2030 közötti időszakra vonatkozó, 2050-ig tartó időszakra kitekintést nyújtó második Nemzeti Éghajlatváltozási Stratégiáról, Budapest. Available online at https://mkogy.jogtar.hu/jogszabaly?docid=A18H0023.0GY, accessed on 02,05,2020

4. Virtual Power Plant Program, 2020. Available online at http://www.mi6.hu/vppp, accessed on 20, 04, 2020

5. Hungarian Nest+ project 2019. Solar Decathlon Europa, Szentendre. Available online at http://www.sde2019.hu/hungarian_nestplus_en.html, accessed on 22, 03, 2020; and https://zoldegyetem.pte.hu/en/news/solar_decathlon_2019 hungarian nest model $h$ ouse has been highly recognized accessed on 22, 04, 2020

6. Scruton, R. 2018. Zöld filozófia. Hogyan gondolkozzunk felelősen a bolygónkról? (Green Philosophy. How to Think Seriously about the Planet.). Akadémiai Kiadó, Budapest, 420 p.

7. Az Év Felelős Foglalkoztatója a Pécsi Tudományegyetem 2019. Pécsi Tudományegyetem, Pécs. Available online at https://csalad.pte.hu/sajto, accessed on 22, 03, 2020

8. Green University 2020. Pécsi Tudományegyetem, Pécs. Available online at https://zoldegyetem.pte.hu/en, accessed on 22, 03, 2020

9. V4 Green Universities (V4GU) 2020. Pécsi Tudományegyetem, Pécs. Available online at https://zoldegyetem.pte.hu/en/v4gu, accessed on 22, 03, 2020 
10. Zero Emission Days 2019. Available online at https://zoldegyetem.pte.hu/en/zeroemission-days, accessed on 22, 03, 2020

11. Baranyai Virtuális Erőmú Program (BAVEP) 2019. Available online at http://www.mi6.hu/bavep, accessed on 22, 03, 2020 